5. Зиновьева Ю. Взаимодействие музея и общества как социокультурная проблема : автореф. дисс. на соискание учёной степени канд. культурологии : спец. 24.00.03 «Музееведение, консервация и реставрация историко-культурных объектов». СПб. 2000. 19 с.

6. Москвічова Ю.О. Музейна панорама сучасної Вінниччини. Народознавчі студії пам'яті В. Т. Скуратівського : Збірник наукових праць [редкол. : С. М. Садовенко - голова редкол., упор., відп. за вип.; 3. О. Босик - упор., відп. ред.], Київ, 23-24 жовтня 2012 р. К. : НАКККіМ, 2012. C. 235-240.

7. Пантелейчук I.В. Трансформація музею як соціокультурного інституту (XX - початок XXI століття) : автореф. дис. на здобуття наук. ступеня канд. іст. наук : спец. 17.00.01. «Теорія та історія культури». Київський національний університет культури і мистецтв. К., 2006. 22 с.

DOI https://doi.org/10.30525/978-9934-26-004-9-13

\title{
WOULD IRONY SAVE CULTURE?
}

\author{
Ovchynnikova A. P. \\ Doctor of Art History, Professor, \\ Head of the Department of Art History \\ and General Humanitarian Disciplines \\ International Humanitarian University \\ Odesa, Ukraine
}

When the era of high technology began, three famous dystopian authors of the 20th century were no longer alive. Two of them - E. Zamyatin and G. Orwell were concerned about the possibility of using the achievements of technical progress in the interests of totalitarian power. Zamyatin warned that dictators could forcibly apply these achievements for lobotomies: they would «cut out» their subjects' fantasy and, thereby, the desire for freedom (the novel «We»). Likewise, Orwell (in his «1984» novel) foresaw that a Ministry of Truth would use propaganda to force all citizens to think orderly. Only the third famous dystopist - Aldous Huxley («Brave New World») - expected big problems just from what were considered positive achievements of progress.

If Orwell was worried about the banning of books, Huxley foresaw just the opposite: there would be no need to ban books, since no one would read them. Orwell admitted that people could be deprived of information, Huxley was afraid that the flow of information would be so great that a person would not 50 
be able to digest it and would degrade to complete passivity and egoism. Orwell warned that they would deliberately hide the truth from a person, Huxley was afraid that freedom of speech would conflict with freedom of hearing, that it would simply drown in a sea of useless information noise.

Orwell feared that culture itself would submit to a slave ideology. Huxley, on the other hand, foresaw that as a result of the «uprising of the masses» (the term of José Ortega y Gasset), it would become massive, and therefore primitive, filled with ersatz substitutes for feelings. According to Huxley, all civil rights activists and rationalists did not take into account that a person has a limitless desire for entertainment. Orwell's people are controlled by causing them pain. Huxley's people are controlled by dosing them with pleasure.

Today, with the naked eye, one can see a lack of trust in cultural values. The globalization of the means of virtual communication has led, on the one hand, to the democratization of culture, and on the other, to its «averaging», to the fact that it seems that everyone can master it - without making any special efforts, without spending labor. This can be seen especially clearly in the functioning of the language. Why know grammar and spelling if the computer will indicate errors? Why read and remember what you have read when you can instantly find anything you want in electronic libraries? Why, in general, strive for the heights of culture, if communication with partners exists in blogs, chats, participation in electronic forums, various happenings, performances, etc. Does it require a «clip» style of material presentation, which means the same thinking?

We are witnessing a language explosion. Changes in society cannot fail to cause changes in the language. This is a natural phenomenon; a new communication has arisen, which has three components: 1) There is reality; 2) There is a «text» - my knowledge about it; 3 ) There is a discourse - what I communicate with, in what way I communicate. If earlier oral and written communication methods were known, now an intermediate one has arisen, i.e. in form - written, in structure and content functions - oral. The language on the Internet is not the language of traditional literature. Phenomena appeared that were completely uncharacteristic for written speech. This is not an ordinary linear written speech, but mutational, almost all prohibitions have been removed. Now there has been a qualitative shift in this regard. The risk of being misunderstood is increasing.

Some words from criminal jargon migrate to official documents. But still, for instance, in France there is a rather tough correlation between the ability to express one's thoughts competently and promotion through the career ladder. Jean Baudrillard called this «linguistic capital». But this is more the exception than the rule. Meanwhile, in a society where there are standards for a literary 
language, there is also a stratification of society: by what language a person uses, one can determine to which stratum of society he belongs. In a stable society, such stratification is important. In an unstable society, other characteristics are important, for example, energy, mobility, and the availability of financial opportunities. It turns out that correct communication is one of the conditions for the transition to a stable society.

In Eastern Europe, the transition to an information society is further complicated by a radical change in the social structure, the destruction of customary cultural institutions, a change in ideological guidelines, the erosion of previous moral norms, a transition to a different legal consciousness and the growth of marginal forms of legal nihilism, the actualization of the ideas of nationalism and various kinds of sectarianism. The old ones, whatever they were, are disappearing, the demand for new paradigms has opened, but the demand, alas, exceeds the supply. Education without paradigms inevitably enters a period of crisis.

Critics are presaging the forthcoming of a new wave of militant writers (for "legalization" they are called postmodernists, or even "anti-culture"). For these new writers, profanity is the norm of the language, and the classics of culture are terra incognita: «why know them if they lived a long time ago?» Ignorance becomes legitimate. Economic principles should flow from the tasks facing society. In a new society, these principles would be reasonable sufficiency, lack of competition, planned, low-waste production, preferential use of renewable energy sources, limited accumulation of money, property and means of production in private hands, relatively even distribution of the product, reasonable automation and computerization of production systems and services. Provision of employment in accordance with the capabilities and interests of a person, a minimum guaranteed income. Almost all of these ideas and principles are well known. However, this is possible only in a society that respects a high culture based on reasonable and moral principles.

What is the reaction of intellectuals to cultural crises? Saving themselves personally and their readers, they dress up in the life jacket of irony, bringing the reality they have inherited to the point of absurdity. So, it was from the old days - from Socrates to Erasmus of Rotterdam, from La Rochefoucauld to A. Chekhov, from St. Jerzy Lec to M. Zhvanetsky. Irony is a grotesque that brings a life situation to the point of absurdity (theater of the absurd). Often the ironic pretends to be more stupid than he is, irony is slyness, allegory, words acquire meanings that are opposite to their direct meaning. And so that she does not provoke retaliatory aggressive actions, the ironic willingly makes fun of himself. A mask of seriousness distinguishes irony from humor and satire. The meaning of irony has changed in different eras. Antiquity was characterized by «Socratic irony», which expressed the principle of doubt and 
at the same time a way of discovering truth. Socrates pretended to be a likeminded opponent, assented to him and imperceptibly brought his point of view to the point of absurdity, revealing the limitations of obvious truths.

German romantics expanded the understanding of irony to the ideological principle: irony should be directed to everything without a trace - both in the realm of real life and in the sphere of spiritual life. It was required to move freely from one opinion to another, emphasizing the relativity of all the established «rules». The spirit of buffoonery must prevail. In this position, they saw an expression of freedom - the highest value. The lifejacket of irony seems to its adepts almost like a bulletproof vest and the best manifestation of intellectual sanity. And what is the irony - will it really save the culture? Suppose we have fully mastered the art of irony. Will we thereby correct the flaws in culture? Maybe you really shouldn't worry about what is happening? Should we not agree with the fact that ignorance is legalized, legitimized? After all, in the Middle Ages, ignorance was accepted as the norm. Charles the tenth signed with a cross (although, at the same time, he gathered intellectuals of that time in his yard). People understood that everything happens against the will of an ordinary person. At the same time, the elite remained the elite, and the masses - the masses. They always rebelled, but when the waves calmed down, the quiet self-righteousness of the top and this very irony of the intellectual elite was revealed. The salvation of cultural values lies, perhaps, on a different plane. In the situation of the collapse of the Roman Empire, the intellectual elite of that time was also concerned about preserving the accumulated information for posterity. In the V century. the writer Marcian Capella, no longer hoping to suspend the process of the barbarization of public consciousness, tried to at least fix the level of ancient education. He systematized seven ancient disciplines - grammar, rhetoric, dialectics (which meant logic), arithmetic, geometry, astronomy and music. Anacius Boethius (480-524) was also concerned about the same, and he hastened to translate the first four books of the Principles of Euclid. The work was not at all pointless. It is largely thanks to these efforts that science has managed to maintain its foundations to this day.

And now, in conditions when culture is increasingly being outsourced to traders, the intelligentsia, saving themselves and their readers, is hiding behind irony. However, if she feels responsible for the legacy inherited from previous generations, irony will not save the culture. A lifejacket keeps you afloat, but does not guarantee that you will get to the shore. A different kind of effort is needed. And we must hurry before it's too late. At the same time, one should not create illusions, the work is not easy. Let us not forget, nevertheless, to forget that Boethius, the "master of all services" in the kingdom of the Ostrogoths, was executed... 